\title{
Physiological characteristics of the ctenophore Beroe ovata in Caspian Sea water
}

\author{
Ahmet E. Kideys ${ }^{1, *}$, Galina A. Finenko ${ }^{2}$, Boris E. Anninsky ${ }^{2}$, Tamara A. Shiganova ${ }^{3}$, \\ Abolghaseem Roohi ${ }^{4}$, Mojgan R. Tabari ${ }^{4}$, Mehdi Youseffyan ${ }^{4}$, \\ Mohamad T. Rostamian ${ }^{4}$, Hosseinali Rostami ${ }^{4}$, Hossein Negarestan ${ }^{5}$ \\ ${ }^{1}$ Institute of Marine Sciences, Middle East Technical University, Erdemli, Turkey
${ }^{2}$ Institute of Biology of the Southern Seas, Nachimov Ave. 2, Sevastopol, Ukraine
${ }^{3}$ P. P. Shirshov Institute of Oceanology RAS, 36 Nakhimovskiy Pr., Moscow, Russia
${ }^{4}$ Mazandaran Fisheries Research Center, Sari, Iran
${ }^{5}$ Iranian Fisheries Research Organization (IFRO), No. 297, Fatemi St., Tehran, Iran
}

ABSTRACT: Riparian countries of the Caspian Sea have been evaluating the pros and cons of the predatory ctenophore Beroe ovata as a control agent against the invasive ctenophore Mnemiopsis leidyi, which has enormous adverse impacts on the fishery resources as well as on the biodiversity in this once fertile sea. To assess the viability of $B$. ovata establishment in the Caspian Sea, the survival and some physiological characteristics (feeding, respiration, reproduction and growth) of the predatory ctenophore were studied in Caspian Sea water (12.6 ppt salinity) conditions using animals transported from the Black and Marmara Seas to a laboratory on the Iranian Caspian coast. The findings of the study showed that when salinity was gradually decreased from 22 to $12.6 \mathrm{ppt}, B$. ovata were able to adapt well to Caspian Sea water. Most of the predatory ctenophores began to swim actively and to feed on $M$. leidyi within 15 to 30 min following each step of acclimation. The feeding rate of $B$. ovata ranged from 14 to $765 \%$ of body wet weight and was highest for smaller individuals (i.e. 13 to $16 \mathrm{~mm}$ ). Over the measured weight range of 0.23 to $3.87 \mathrm{~g}$ wet wt, the weight-specific respiration rate was independent of weight. The daily specific growth rate of adult ctenophores was 7 to $11 \%$ of body wet wt. B. ovata specimens were spawned and their eggs were hatched in Caspian Sea water, but the larvae survived for only a few hours. The energy budget of $B$. ovata calculated from food consumption, respiration and growth rates revealed a mean assimilation efficiency of $0.72 \pm 0.1$, a gross growth efficiency $\left(K_{1}\right)$ of $0.48 \pm 0.12$ and a net efficiency $\left(K_{2}\right)$ of $0.66 \pm 0.06$. Based on these physiological data, we suggest that in the Caspian Sea, $B$. ovata will be able to ingest $M$. leidyi intensively. However, concerning the reduction of the $M$. leidyi population and consequently the reversal of its adverse impact on this ecosystem, the failure of larval growth observed under experimental conditions (most probably due to poor handling) remains the main obstacle to overcome in the successful establishment of $B$. ovata in the Caspian Sea.

KEY WORDS: Caspian Sea · Beroe ovata · Mnemiopsis leidyi · Invasion · Survival · Physiology · Energy budget $\cdot$ Mitigation

\section{INTRODUCTION}

At the end of the 1980s, the Black Sea ecosystem experienced an unprecendented impact from the invasion of the ctenophore Mnemiopsis leidyi, a voracious mesozooplankton predator, transported by the ballast waters of ships from the northwestern Atlantic coastal region (Vinogradov et al. 1989). This comb jelly consumed a considerable fraction of the zooplankton (Finenko \& Romanova 2000) that had been the food for pelagic fish and their larvae before its arrival. One of 
the dramatic consequences of the $M$. leidyi invasion was the sharp drop in commercial catches of planktivorous fish (mainly the anchovy Engraulis encrasicolus L.) in the Black Sea (Kideys 1994, Prodanov et al. 1997, Shiganova 1997, 1998).

The arrival, at the end of the 1990s, of another alien ctenophore, Beroe ovata, a known predator of Mnemiopsis leidyi (Kremer \& Nixon 1976), resulted in the significant decrease of the biomass of the latter and hence the recovery of zooplankton and ichtyoplankton quantities (Shiganova et al. 2000, 2001a, Finenko et al. 2001, 2003, Gubanova et al. 2001, Kideys \& Romanova 2001, Kideys 2002). All these studies confirmed that $B$. ovata feeds almost exclusively on $M$. leidyi in the Black Sea. After the B. ovata invasion, the presence of M. lei$d y i$ in this sea was limited to about 2 mo only (i.e. July and August; Finenko et al. 2003) as opposed to its year round notable occurrences in the past (Mutlu 1999). Presently, when $M$. leidyi reaches peak values in this period, B. ovata starts to increase sharply and within $2 \mathrm{wk}$ this predator decimates the levels of $M$. leidyi very effectively (Finenko et al. 2003). As a consequence of this top-down control, considerable increases in copepod abundance as a whole, and some copepod species (Acartia clausi, Paracalanus parvus, Centropages ponticus) in particular, were observed in the last 2 to $3 \mathrm{yr}$ (Finenko et al. 2003), during which time catch values of Turkish pelagic fishery from the Black Sea has been at record levels (A. E. Kideys 2002, unpubl.).

A warning that Mnemiopsis leidyi might also invade the Caspian Sea had been voiced as early as 1995 (Dumont 1995, GESAMP 1997). Unfortunately, at the end of the 1990s the invasion of M. leidyi in the Caspian Sea was already being reported (Ivanov et al. 2000). It must have also been transported in the ballast waters of ships traveling from the Black Sea (salinity generally $18 \mathrm{ppt}$ ) or the Sea of Azov (where M. leidyi occurs in warm months) to the Caspian Sea (salinity generally 12 to $13 \mathrm{ppt}$ ) through the Volga Don Canal. Investigations in the Caspian Sea showed that in July 2000, M. leidyi was distributed mainly in the middle and southern Caspian Sea. By September 2000, it was found everywhere including the northern Caspian where the salinity can be as low as 4 ppt. The density of $M$. leidyi ranged between 3 and 100 ind. $\mathrm{m}^{-2}$ in July, and in October it increased up to 170 ind. $\mathrm{m}^{-2}$ (Shiganova et al. 2001b). An increasing trend of M. leidyi abundance was noticed in 2001: density and biomass of $M$. leidyi rose significantly in all areas of the Caspian Sea in August 2001 compared with the same season in 2000 (Kideys \& Moghim 2003). The abundance of $M$. leidyi ranged between 61 and 2285 ind. $\mathrm{m}^{-2}$ (or 0.5 to 100 ind. $\mathrm{m}^{-3}$ ) and the wet biomass ranged between 3.5 and $351 \mathrm{~g} \mathrm{~m}^{-2}$ (or 0.02 to $18.6 \mathrm{~g} \mathrm{~m}^{-3}$ ) with an average value of $121 \mathrm{~g} \mathrm{~m}^{-2}$ (or $3.7 \mathrm{~g} \mathrm{~m}^{-3}$ ). It is worth noting that the majority of $M$. leidyi were present above the thermocline (at 25 to $50 \mathrm{~m}$ ) in August 2001.

The impact of Mnemiopsis leidyi on the Caspian Sea ecosystem already seems to be even worse than in the Black Sea due to the greater sensitivity of this closed basin (Kideys et al. 2001a,b, 2002). Within 2 yr, very significant decreases in the quantity of mesozooplankton in the northern (Shiganova et al. 2001b) and southern Caspian Sea (A. Roohi unpubl.) were found. Notable decreases were observed in the pelagic (mainly kilka Clupeonella spp.) fishery of all countries bordering the Caspian Sea: almost a 50\% decrease in the kilka catches of both Iranian and Azerbaijan fisheries had occurred during 1999 and 2001, resulting in great economic losses (Kideys et al. 2001a,b). Russian catches were also reported as decreasing remarkably (Shiganova et al. 2001b). Not only pelagic fishes, but also some large predators feeding on these fish such as white sturgeon Huso huso and the endemic Caspian seal Phoca caspica are also under threat of significant population decrease.

Investigations in the Black Sea have shown that Beroe ovata feeds almost exclusively on Mnemiopsis leidyi and is very effective in controlling its levels (Finenko et al. 2000, 2001, 2003, Kideys et al. 2000, Shiganova et al. 2001a). During the 'First International Workshop on the Invasion of the Caspian Sea by the comb jelly M. leidyi: Problems, Perspectives and the Need for Action', organized by the Caspian Ecological Program (CEP) in April 2001, it was concluded that $B$. ovata is the best candidate for controlling the M. leidyi population in the Caspian Sea. Kideys (2002) also stressed that the control of M. leidyi in the Black Sea through its predator $B$. ovata presented a good example of techniques for dealing with the invasive species problem in regard to other pelagic marine ecosystems in general, and the Caspian Sea in particular.

As a result, the feasibility of Beroe ovata introduction and the evaluation of the potential impact of such an introduction on $M$. leidyi and other pelagic biota in the Caspian Sea, arose as priority issues. In order to evaluate the potential success of its establishment in this environment, we investigated, along with the idea of transporting B. ovata from the Black Sea into the Khazerabad Fisheries Research Laboratory on the Caspian coast of Iran, the survival and basic physiological characteristics (feeding, respiration, growth and reproduction rates) of B. ovata in Caspian Sea water conditions.

\section{MATERIALS AND METHODS}

Acclimation of Beroe ovata to the salinity of Caspian Sea water. Beroe ovata, generally made up of small individuals (10 to $40 \mathrm{~mm}$ ), were transported in 2 
batches to the Khazerabad laboratory (Mazandaran, Iran) on the Caspian coast in September 2001. For the first batch, 30 B. ovata sampled from Sinop, Turkey (southern Black Sea; salinity about 18 ppt) were transported on 11 September in a $10 \mathrm{l}$ jar. Upon arrival, healthy individuals from this batch were put into separate tanks (5 l) for $1 \mathrm{~d}$ at $26 \pm 1^{\circ} \mathrm{C}$ in conditions of original salinity. On the next day and for the next $24 \mathrm{~h}$, the salinity was decreased to about $16 \mathrm{ppt}$, then the individuals were transferred into containers filled solely with Caspian Sea water (12 to $13 \mathrm{ppt}$ ).

For the second batch, about 60 Beroe ovata were collected from the Bosphorus, at the Sea of Marmara (salinity around $22 \mathrm{ppt}$ ) and flown to Iran on $13 \mathrm{Sep}-$ tember 2001. Upon arrival to the laboratory, the healthy looking specimens of $B$. ovata were put into a large tank (15 l) in a temperature-controlled room of $21 \pm 1^{\circ} \mathrm{C}$. The acclimation of the Black Sea B. ovata to the lower salinity Caspian Sea water was carried out by changing the salinity step by step from 22 to 12.6 ppt: after the first $4 \mathrm{~h}$ the salinity was decreased to $17.4 \mathrm{ppt}$ with filtered Caspian Sea water sampled off the coast of Khazerabad (12.6 ppt); during the next few days the salinity was decreased every 9 to $17 \mathrm{~h}$ with intermediate salinities of 15.0,13.5, and finally, 12.6 ppt. Lastly, the behavior of the animals in the new saline conditions was observed, however we did not, unfortunately, keep some of the animals under original salinity as a control group for comparative purposes.

All containers were aerated. After the Beroe ovata acclimated to the salinity of the Caspian Sea, experiments concerning its feeding, respiration, growth and reproduction rates began.

Estimation of ingestion rate and digestion time. To determine the feeding rate of Beroe ovata, several experiments were run starting on 15 September 2001. The first 2 series of short-term $(24 \mathrm{~h})$ experiments were conducted at $21 \pm 1^{\circ} \mathrm{C}$ using Marmara specimens. In the first series, a total of 15 B. ovata were individually placed in $3.5 \mathrm{l}$ containers along with 12 Mnemiopsis leidyi specimens of 4 different size groups $(<5,5-10$, 11-15 and 16-30 mm, 3 ctenophores from each size group) as food. Another (16th) container containing only $12 \mathrm{M}$. leidyi without $B$. ovata was kept as a control. The length of $B$. ovata in this experiment ranged from 13 to $35 \mathrm{~mm}$. All B. ovata were starved for at least $24 \mathrm{~h}$ before the feeding experiment.

This experiment was designed so that all bottles were monitored every $30 \mathrm{~min}$ for a $24 \mathrm{~h}$ period. In this way, in addition to the feeding rate, we could determine prey-size preference, digestion time with respect to the prey:predator ratio as well as the interval between the 2 subsequent consumptions in Beroe ovata.
In these conditions, Beroe ovata had many prey available and could feed ad libitum over the whole period. The total biomass of prey was about $1.66 \pm 0.31$ (mean \pm standard deviation) $g$ wet wt $\mathrm{l}^{-1}$. The numbers and length of Mnemiopsis leidyi in the containers were counted and measured at the beginning and end of the experiment, with the difference reflecting the daily ingestion rate (number or biomass of prey that $1 \mathrm{~B}$. ovata consumed per day). To estimate the ration in weight units, a respective total length/wet weight $\left(L, \mathrm{~mm}_{i} W_{\text {, }}\right.$ g) equation obtained for the Caspian $M$. leidyi in July 2001 was used: $W=0.0011 \times L^{2.34}\left(\mathrm{R}^{2}=0.65, \mathrm{n}=98\right.$, range 3 to $22 \mathrm{~mm}$; Kideys \& Moghim 2003). B. ovata length was converted to wet wt by using the equation $W=0.00177 \times L^{2.23}\left(\mathrm{n}=22 ; \mathrm{r}^{2}=0.982 ;\right.$ size range 14 to 120 mm; Finenko et al. 2001).

The second series of feeding experiments at $21 \pm 1^{\circ} \mathrm{C}$ (again using Marmara specimens) were conducted in a total of 34 tanks including 1 predator each. This experiment was run to determine the ration value for 3 different sizes of the prey Mnemiopsis leidyi (5 to 6, 10 and 20 to $40 \mathrm{~mm}$ ) having the same biomass (about $1 \mathrm{~g}$ $\mathrm{l}^{-1}$ ). Not all the tanks had the same number of prey; the number was determined in order to have the total biomass of prey equivalent in each tank. This differed from the first experiment in that the predator did not have the option of selecting the size of prey, but was only offered 1 size group of the $M$. leidyi to consume.

A separate feeding experiment was designed at $26 \pm$ $1^{\circ} \mathrm{C}$ during $16-30$ September to determine the digestion time with respect to the size ratio of prey and predator (by using Beroe ovata brought from the Black Sea). The size ranges of prey and predators are given in the next paragraph. In contrast to the first series of experiments these animals were not starved before the experiment. Once ingestion occurred, the B. ovata specimens were monitored in their container (without being isolated) every $15 \mathrm{~min}$ until defecation was completed and the gut was empty. Then, knowing the size distribution and density of both ctenophores from field data, this relationship could be used to calculate the maximum potential ingestion rate at sea.

Additionally, to study feeding and growth rates together, from 16 to 30 September, a longer experiment (14 d) was performed at $26 \pm 1^{\circ} \mathrm{C}$ by using Beroe ovata specimens of the Black Sea. Five $B$. ovata specimens with an initial wet wt of 3.17 to $4.64 \mathrm{~g}$ (length 30 to $35 \mathrm{~mm}$ ) were placed individually in 4.21 containers where 5 to 15 specimens of Mnemiopsis leidyi (length 10 to $30 \mathrm{~mm}$ ) had been added, making a concentration of about 1 ind. $\mathrm{l}^{-1}$. The number of $M$. leidyi in the containers was counted daily and new prey were added to maintain the initial prey concentration. It is worth noting that although food supply was not thought to be in limitation at this concentration, the results found later 
(see Fig. 2) indicated that the B. ovata had in fact not fed to satiation.

Growth rate. The growth rate was estimated simultaneously with the ration study in the above long-term experiment at $26 \pm 1^{\circ} \mathrm{C}$. It was estimated in each container every day at the same time from regular measurements of the Beroe ovata length. The B. ovata wet wt was determined from its length as in the feeding experiments.

Respiration rate. Respiration rates were measured on 22 September using a total of 21 Beroe ovata at a temperature of $21 \pm 1^{\circ} \mathrm{C}$. Individual ctenophores were not fed during the experiment and were kept in the dark in respiration chambers (0.25 l) filled with $112 \mu \mathrm{m}$ filtered seawater for 7 to $18 \mathrm{~h}$, depending on the size of the ctenophore. The concentration of dissolved oxygen was not allowed to decrease more than $10 \%$ of the initial concentration. The dissolved oxygen content was determined by the Winkler method (Strickland \& Parsons 1972).

Reproduction. With the aim of observing the eggs under binocular microscope, tanks with Beroe ovata from each experiment (at 21 and $26^{\circ} \mathrm{C}$ ) were checked every morning following the back filtration of water from the tanks. Thus, the bulk of water was also exchanged every day.

Eggs and early embryos obtained from the fed specimens of Beroe ovata in the tanks with Caspian Sea water were transferred both to beakers (i.e. 100 to $200 \mathrm{ml}$ ) and to a set of smaller containers (about $5 \mathrm{ml}$ ) where they were examined every several hours to observe the hatching and the development of $B$. ovata in Caspian Sea water.

Energy content. All the major organic components of the tissue (proteins, lipids, carbohydrates, amino acids) of Mnemiopsis leidyi were quantitatively assayed by routine colorimetric techniques as described earlier (Anninsky 1994). According to their chemical composition, the energy contents of these $M$. leidyi specimens were then calculated by taking the calorific value of each main biochemical compound into account (i.e.

Table 1. Number of Mnemiopsis leidyi eaten from each size group by Beroe ovata in the first feeding experiment. Number of $M$. leidyi offered is shown in parentheses. The number of prey offered was 3 for each of the 4 size groups of M. leidyi per individual B. ovata

\begin{tabular}{|lcccc|}
\hline \multirow{2}{*}{$\begin{array}{l}\text { M. leidyi } \\
\text { length (mm) }\end{array}$} & \multicolumn{3}{c|}{ B. ovata length } & \multirow{2}{*}{ Total } \\
\cline { 2 - 4 } & $\begin{array}{l}\text { 7 specimens } \\
\text { of } 13-20 \text { mm }\end{array}$ & of 21-27 mm & of 28-35 mm & \\
\hline$<5$ & $7(21)$ & $4(15)$ & $6(9)$ & $17(45)$ \\
$5-10$ & $2(21)$ & $4(15)$ & $4(9)$ & $10(45)$ \\
$11-15$ & $3(21)$ & $5(15)$ & $7(9)$ & $15(45)$ \\
$16-30$ & $10(21)$ & $14(15)$ & $8(9)$ & $32(45)$ \\
Total & $22(84)$ & $27(60)$ & $25(36)$ & $74(180)$ \\
\hline
\end{tabular}

$5.65 \mathrm{cal} \mathrm{mg}^{-1}$ for proteins, $9.45 \mathrm{cal} \mathrm{mg}^{-1}$ for lipids and $4.10 \mathrm{cal} \mathrm{mg}^{-1}$ for carbohydrates; B. E. Anninsky et al. unpubl. data). Unfortunately, no chemical analyses were performed for Beroe ovata and therefore the values used for this species were those that had already been determined in previous analyses performed at the Black Sea (Finenko et al. 2001).

\section{RESULTS}

\section{Acclimation of Beroe ovata to the salinity of Caspian Sea water}

After the salinity was changed from 22 to $17.4 \mathrm{ppt}$ the Beroe ovata (collected from the Bosphorus) first gathered near the bottom of the container. Some specimens even stopped beating their cilia. After $20 \mathrm{~min}$, almost all B. ovata specimens were again active, both in the water column and near the bottom. In the following 10 to $30 \mathrm{~min}$, they were swimming in the water column and had Mnemiopsis leidyi in their stomachs. During the consecutive transfers from high to low salinities $(17.4,15.2,13.5$ and $12.6 \mathrm{ppt})$ they were in normal condition and did not show any behavioral change. Within 15 to $30 \mathrm{~min}$ of each transfer, most of the $B$. ovata specimens had begun to swim actively and feed on $M$. leidyi.

The Beroe ovata (collected from Sinop, southern Black Sea) transferred from 18 to 16 ppt and then into the Caspian water did not stop beating their cilia, and continued to feed and swim as they did in the Black Sea water.

\section{Ration and digestion time in Beroe ovata}

In the first series of short-term $(24 \mathrm{~h})$ feeding experiments, the same amount of Mnemiopsis leidyi of different biomass were offered to Beroe ovata in 4 different size groups. All sizes of B. ovata intensively consumed all sizes of $M$. leidyi offered (Table 1). However, the largest M. leidyi specimens were preferred by all the different size groups of the predator ctenophore. In terms of biomass, small $M$. leidyi (<5 mm) were not consumed intensively and composed an insignificant part of the daily ration: $2.6 \%(\mathrm{n}=7)$ for B. ovata with a length of 13 to $20 \mathrm{~mm}, 1.0 \%(\mathrm{n}=4)$ for B. ovata with a length of 21 to $27 \mathrm{~mm}$ and $4.5 \%$ ( $\mathrm{n}=6$ ) for the largest $B$. ovata with a length of 28 to $30 \mathrm{~mm}$. Thus, under conditions of possible selection and 


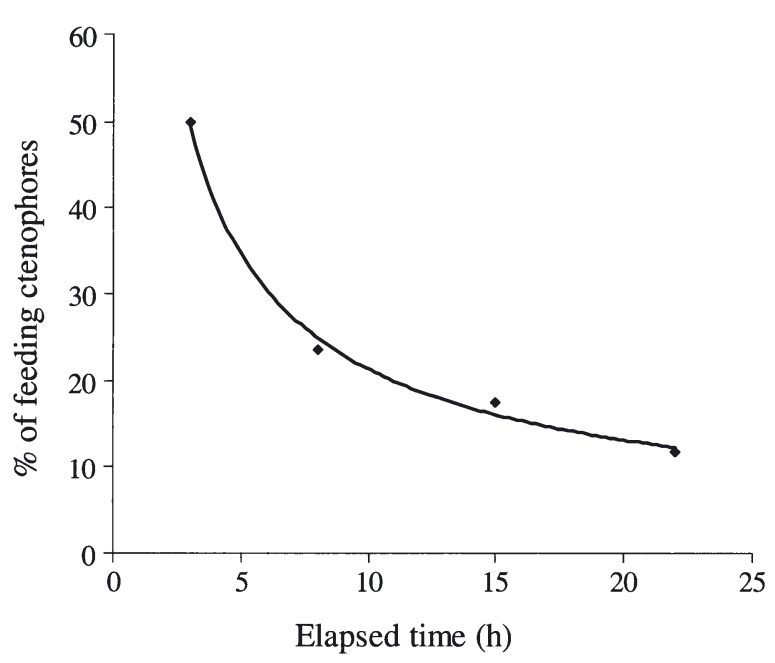

Fig. 1. Beroe ovata. Decrease in feeding intensity during the first short-term feeding experiment. Animals were starved for $24 \mathrm{~h}$ before the experiment

high prey density (number per volume), B. ovata preferred large and medium-sized $M$. leidyi to meet their food requirements. The daily rations were very high and ranged from 45 to $765 \%$ of B. ovata body wet wt, the highest being found in small $B$. ovata (13 to $20 \mathrm{~mm}$ ). In this short-term experiment, where B. ovata were starved prior to the experiment, the feeding intensity decreased sharply throughout the $24 \mathrm{~h}$ experimental period (Fig. 1). While almost $50 \%$ of B. ovata fed within the first $3 \mathrm{~h}$, only $25 \%$ had engulfed prey within the next $3 \mathrm{~h}$ and the remainder were observed feeding during the following $18 \mathrm{~h}$ of the experiment.

In the second series of feeding experiments, Mnemiopsis leidyi of different sizes were offered to individual Beroe ovata specimens $(\mathrm{n}=34)$ in equal biomass concentrations (about $1 \mathrm{~g}$ wet wt $\mathrm{l}^{-1}$ ) but separately and in different quantities. The maximum daily rations of $B$. ovata were observed when they consumed large $M$. leidyi, but they could intensively ingest the small $M$. leidyi too, and the ranges for specific daily rations were very close to each other when feeding on different sizes of $M$. leidyi (Table 2). The weight specific ration had the largest range of 13.7 to $267 \%$ for B. ovata of 9 to $30 \mathrm{~mm}$ feeding on $M$. leidyi of $5 \mathrm{~mm}$ in length.

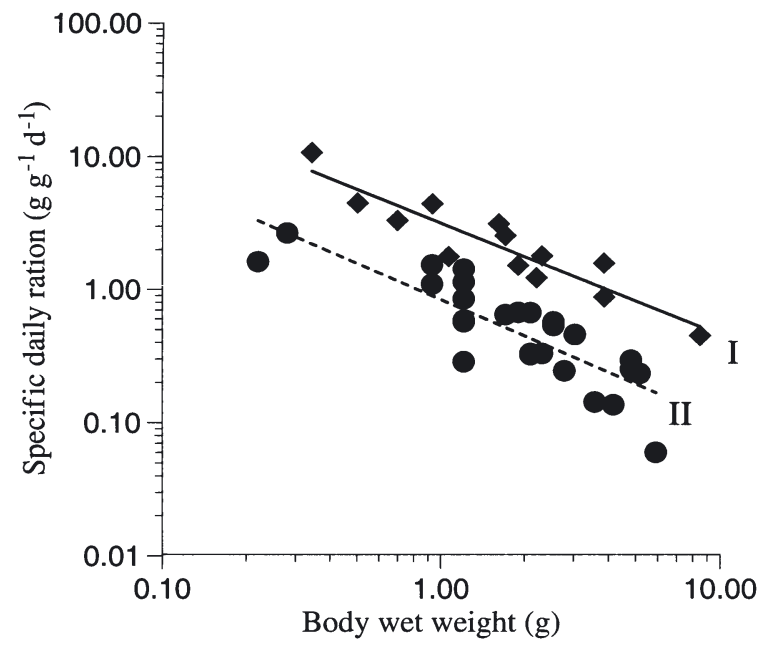

Fig. 2. Beroe ovata. Effect of body weight on specific daily ration (SDR) at $1.66 \mathrm{~g} \mathrm{l}^{-1}$ (I: first short-term feeding experiment; $\mathrm{SDR}=3.18 W^{-0.84}, \mathrm{r}^{2}=0.85$ ) and $1.00 \mathrm{~g} \mathrm{l}^{-1}$ (II: second short-term feeding experiment; $\mathrm{SDR}=0.84 W^{-0.90}, \mathrm{r}^{2}=0.70$ ) food concentrations, both at $21^{\circ} \mathrm{C}$

The relationship between the specific daily ration (SDR, $\mathrm{g} \mathrm{g}^{-1} \mathrm{~d}^{-1}$ ) and Beroe ovata wet wt at 2 different types of prey biomass $\left(\mathrm{I}=1.6\right.$; $\mathrm{II}=1.0 \mathrm{~g} \mathrm{l}^{-1}$ ) (Fig. 2), could be described with 2 different power functions:

$$
\begin{array}{lll}
\text { I } & \text { SDR }=3.184 W^{-0.841} & \mathrm{r}^{2}=0.852 \\
\text { II } & \text { SDR }=0.842 W^{-0.904} & r^{2}=0.701
\end{array}
$$

The difference between specific daily rations at tested food conditions showed that food concentration is an important factor in B. ovata feeding.

The digestion time for Beroe ovata feeding on Mnemiopsis leidyi at $21^{\circ} \mathrm{C}$ ranged from 65 to $210 \mathrm{~min}$ in the studied length range of both ctenophores (13 to $24 \mathrm{~mm}$ for B. ovata and 2 to $18 \mathrm{~mm}$ for M. leidyi). The interval between the following 2 consumptions was $415 \pm$ $298 \mathrm{~min}$ on average. Each size of B. ovata consumed both small and large $M$. leidyi, however neither predator nor prey size analyzed separately had a statistically significant effect on digestion time (according to the regression analysis at $5 \%$ confidence level). On the other hand the prey:predator weight ratio appeared to be effective concerning digestion time in regard to the

Table 2. Daily rations (g ind..$^{-1} \mathrm{~d}^{-1}$ ) and weight specific daily rations (\%) of Beroe ovata feeding on different sized Mnemiopsis

\begin{tabular}{|c|c|c|c|c|c|c|}
\hline $\begin{array}{l}\text { B. ovata length } \\
(\mathrm{mm})\end{array}$ & $\begin{array}{l}\text { M. leidyi length } \\
(\mathrm{mm})\end{array}$ & $\begin{array}{l}\text { No. of } M \text {. leidyi } \\
\text { per jar }\end{array}$ & $\begin{array}{l}\text { No. of } M \text {. leidyi eaten } \\
\text { at end of } 24 \mathrm{~h} \text { expt }\end{array}$ & $\begin{array}{l}\text { Ration } \\
\text { (g ind } .^{-1} \mathrm{~d}^{-1} \text { ) }\end{array}$ & $\begin{array}{l}\text { Weight-specific } \\
\text { daily ration (\%) }\end{array}$ & $\mathrm{n}$ \\
\hline $9-30$ & 5 & 50 & $19.2 \pm 7.3$ & $0.51-1.73$ & $13.7-267.0$ & 12 \\
\hline $10-32$ & 10 & 10 & $3.1 \pm 2.0$ & $0.35-2.49$ & $28.8-162.0$ & 14 \\
\hline $20-35$ & $20-40$ & 3 & $2.4 \pm 0.7$ & $1.22-6.17$ & $25.2-238.0$ & 8 \\
\hline
\end{tabular}
leidyi in the second series of experiments (prey concentration is about $1 \mathrm{~g}$ wet wt ${ }^{-1}$ ) 


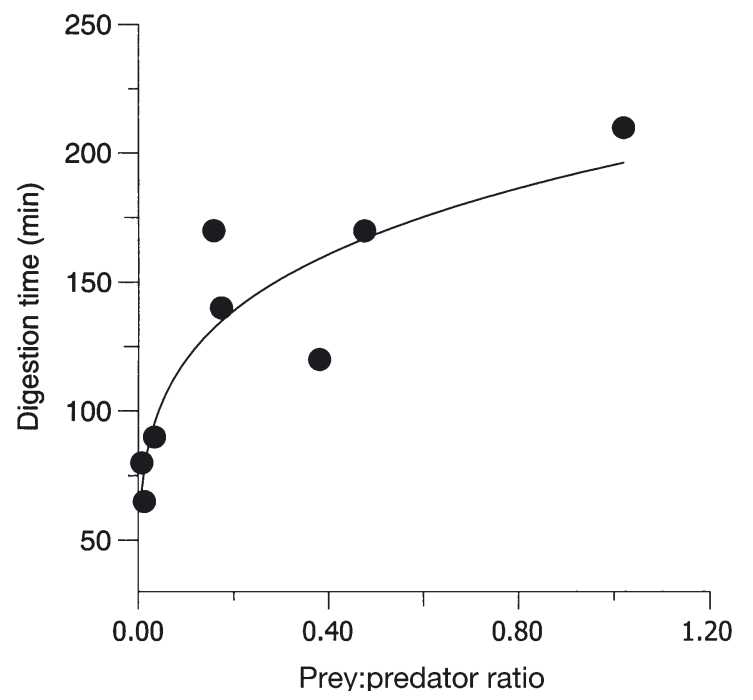

Fig. 3. Beroe ovata. Effect of prey:predator weight ratio $(P)$ on digestion time $(D)$ at $21^{\circ} \mathrm{C}$

following equation with its high coefficient of determination (Fig. 3):

$D=195.5 \mathrm{P}^{0.212}, \mathrm{r}^{2}=0.83,0.013<\mathrm{p}<1.0\left(\right.$ for $21^{\circ} \mathrm{C}$ )

where $D$ is digestion time in min and $P$ is prey:predator weight ratio. At $26^{\circ} \mathrm{C}$, the digestion time did not fit the prey:predator ratio well, although it averaged $99 \pm 57 \mathrm{~min}$ for B. ovata and M. leidyi of 25 to 42 and 10 to $20 \mathrm{~mm}$ in length, respectively.

\section{Ingestion rate in long-term experiments}

The rations in these experiments were obtained for ctenophores in conditions of permanent presence of prey, although some experimental tanks were later revealed as not having an unlimited food supply (see Fig. 2). Despite this, there was a strong periodicity in feeding (Fig. 4) which was not related to light conditions or to the time of day, but more to the intensity of the pre-

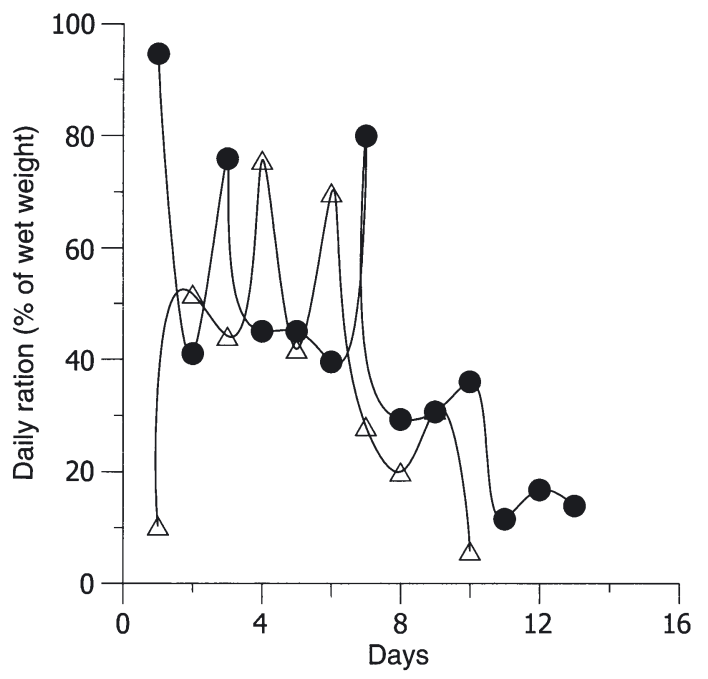

Fig. 4. Beroe ovata. Changes in daily ration rates of 2 specimens in long-term experiments at $26^{\circ} \mathrm{C}$. Both specimens had initial lengths of $30 \mathrm{~mm}$. Average daily ration in one of the specimens $(\bullet)$ is $40.2 \pm 27.0 \%$, in the other $(\Delta) 37.9 \pm 23.4 \%$

vious feeding; ingestion of a large portion of food was followed by a low feeding rate. The average daily rations during this $14 \mathrm{~d}$ experiment ranged from 26 to $43 \%$ wet wt for the 5 individuals with an initial wet wt of 3.2 to $4.6 \mathrm{~g}$ that could vary between 0 to $95 \%$ wet wt per day.

\section{Respiration rate}

The relationship between the oxygen consumption rate $\left(R, \mathrm{ml} \mathrm{O}_{2}\right.$ ind. $\left.^{-1} \mathrm{~h}^{-1}\right)$ and wet wt of Beroe ovata $(W, \mathrm{~g})$ at $21^{\circ} \mathrm{C}$ was expressed by the equation (Fig. 5):

$$
R=0.0052 W^{1.02}, \quad \mathrm{r}^{2}=0.91
$$

The weight-specific coefficient was 1.02, indicating that the weight-specific respiration rate is independent of weight over the measured wet wt range $(0.23$ to $3.87 \mathrm{~g})$.

Table 3. Beroe ovata. Daily energy budget (cal ind. ${ }^{-1} \mathrm{~d}^{-1}$ ) in the longer experiment. The measured parameters are $C, R$ and $G ;$ the calculated parameters are $A, a, K_{1}$ and $K_{2}$. Energy content in Mnemiopsis leidyi is $6.8 \mathrm{cal} \mathrm{g}^{-1}$ wet wt (B. Anninsky et al. unpubl.), and in B. ovata it is $17 \mathrm{cal} \mathrm{g}^{-1}$ wet wt (Finenko et al. 2001). Oxygen consumption was converted to units of energy using the oxycalorific coefficient of $4.86 \mathrm{cal} \mathrm{ml}^{-1} \mathrm{O}_{2}$

\begin{tabular}{|lccccccc|}
\hline $\begin{array}{l}\text { Initial } \\
\text { wet wt }(\mathrm{g})\end{array}$ & $\begin{array}{c}\text { Daily ration } \\
C\end{array}$ & $\begin{array}{c}\text { Respiration } \\
\text { rate } R\end{array}$ & $\begin{array}{c}\text { Growth } \\
G\end{array}$ & $\begin{array}{c}\text { Assimilated } \\
\text { food } A\end{array}$ & $\begin{array}{c}\text { Assimilation } \\
\text { efficiency } a\end{array}$ & $\begin{array}{c}\text { Gross growth } \\
\text { efficiency } K_{1}\end{array}$ & $\begin{array}{c}\text { Net growth } \\
\text { efficiency } K_{2}\end{array}$ \\
\hline 3.17 & 18.06 & 4.73 & 11.27 & 16 & 0.88 & 0.62 & 0.70 \\
3.17 & 10.73 & 2.89 & 4.1 & 6.99 & 0.65 & 0.38 & 0.59 \\
3.17 & 17.11 & 3.57 & 7.7 & 11.27 & 0.65 & 0.45 & 0.68 \\
Average \pm SE & & & & & $0.73 \pm 0.08$ & $0.48 \pm 0.07$ & $0.66 \pm 0.04$ \\
\hline
\end{tabular}




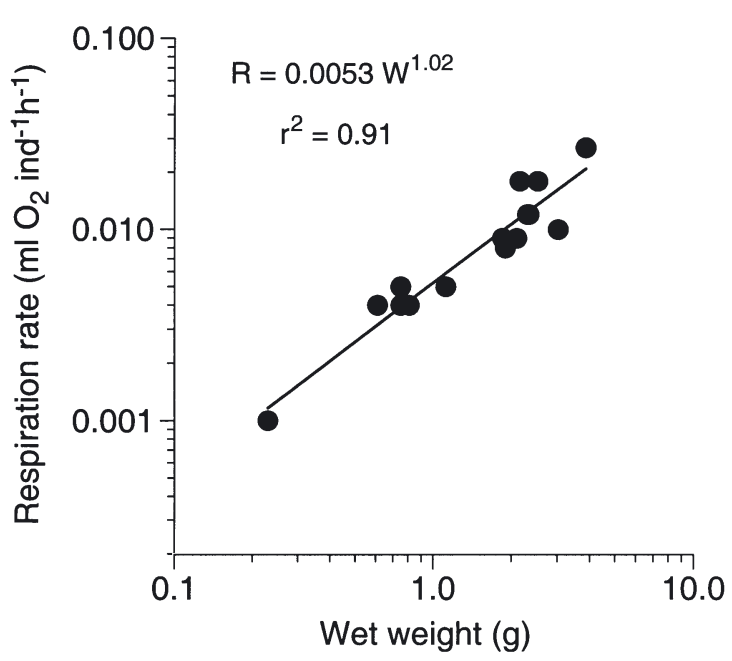

Fig. 5. Beroe ovata. Relationship between respiration rate $\left(R, \mathrm{ml} \mathrm{O}_{2}\right.$ ind $\left.^{-1} \mathrm{~h}^{-1}\right)$ and wet weight $(W, \mathrm{~g})$ at $21^{\circ} \mathrm{C}$

\section{Growth rate and energy budget}

Of the 4 specimens selected for this experiment, the growth of 3 specimens (initial wet wt of $3.17 \mathrm{~g}$ each; Table 3 and Fig. 6) was recorded, as only one did not grow and decreased its weight despite being fed. The mean daily ration of the latter ctenophore was minimal $(25.8 \pm 9.6 \%$ wet wt) compared to the other 3 specimens. The reason for the low feeding intensity of this specimen could be either the damage observed around the mouth (perhaps due to frequent contact with the walls of the small 4 l container) or some peculiarities in its physiological condition.

The wet wt for the 3 Beroe ovata of similar initial weight $(3.17 \mathrm{~g})$ increased during the experiment and their growth could be expressed with exponential functions with growth coefficients ranging from 0.067 to 0.115 (Fig. 6).

The energy budget of Beroe ovata was calculated on the basis of food consumption, respiration and growth rates obtained in long-term experiments (Table 3). From our measurements, the average value regarding energy content for all sizes of Mnemiopsis leidyi was $6.8 \pm 0.2 \mathrm{cal} \mathrm{g}^{-1}$ wet wt (B. Anninsky et al. unpubl.), which was similar to values calculated from the Black Sea measurements (Anninsky 1994). Unfortunately, to calculate the energy budget of ctenophores in our experiments, we did not measure the energy content of B. ovata in Caspian water, but, instead, used the values given by Finenko el al. (2001) for the Black Sea B. ovata caloricity (17 $\mathrm{cal} \mathrm{g}^{-1}$ wet wt).

The mean assimilation efficiency in ctenophores with initial wet wt of $3.17 \mathrm{~g}$ was calculated to be $0.73 \pm 0.09$, and the gross and net growth efficiencies were $K_{1}=$ $0.48 \pm 0.09$ and $K_{2}=0.66 \pm 0.04$, respectively (Table 3 ).

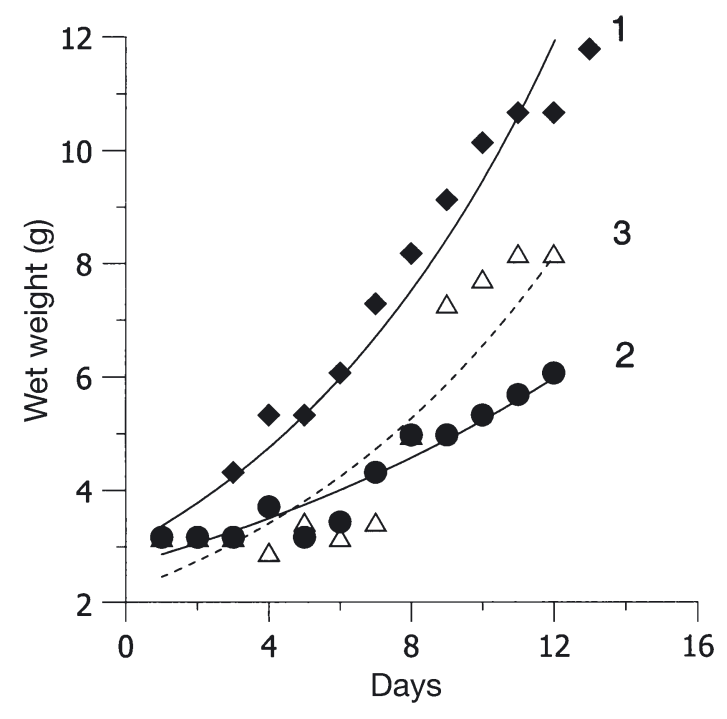

Fig. 6. Beroe ovata. Growth rates of 3 specimens in Caspian Sea water (at $26^{\circ} \mathrm{C}$ ). (1) $W=3.005 \mathrm{e}^{0.115}, \mathrm{r}^{2}=0.959,(2) W=$ $2.689 \mathrm{e}^{0.067}, \mathrm{r}^{2}=0.895$, and (3) $W=2.215 \mathrm{e}^{0.108}, \mathrm{r}^{2}=0.808$

\section{Reproduction}

After $24 \mathrm{~h}$, about 10 and $70 \%$ of the total eggs survived in beakers and in smaller containers, respectively. Only 2 hatched larvae were found; 1 in a beaker and 1 in a small container. After the second 24 h, 20\% of all eggs were still alive but had not developed. One larva in a small container did, however, continue to develop, but after a further $24 \mathrm{~h}$, all embryos and larvae were dead.

During the following days, 2 to 27 of the eggs of fed Beroe ovata, comprising in total 78 eggs, were obtained from different tanks at a temperature of $21^{\circ} \mathrm{C}$. Most of the eggs were obtained from tanks where experiments for $B$. ovata growth were conducted. However, the development of eggs was not successful. Only 5 developed into larvae, which died within a few hours.

Thus, during the experiments, 138 eggs of Beroe ovata were obtained and 7 larvae were hatched. Although we were successful at getting adult $B$. ovata to produce eggs, only a small fraction of these hatched, and no larvae survived after $24 \mathrm{~h}$. It is worthwhile noting that no attempt was made to feed the larvae.

\section{DISCUSSION}

Our experiments showed that Beroe ovata could live and grow in Caspian Sea water. However, B. ovata should be acclimated gradually over a period of a few days from the 18 and 22 ppt of the Black and Marmara Seas, respectively, to the lower salinity of the Caspian 
water. We found also that it is safer not to decrease salinity more than 2 to 3 ppt per day. During our experiments of about 1 mo duration, we managed to keep B. ovata alive in Caspian Sea water (at a salinity of 12.6 ppt and a temperature of $21^{\circ} \mathrm{C}$ ).

The feeding rate for Beroe ovata at salinity $12.6 \mathrm{ppt}$ was high and ranged from 14 to $765 \%$ of body wet wt with the highest values corresponding to small ctenophores (13 to $16 \mathrm{~mm}$ ). These values are close to those assessed at the Black Sea (salinity at $18 \mathrm{ppt}$ ) where the daily ration of adult ctenophores in the experiments with high food abundance was found to range, from the largest to the smallest animals, from 5 to $460 \%$ of body wet wt (Finenko et al. 2003). Ctenophores alternate periods of intensive feeding with periods of starvation or low feeding. They can ingest enough food at one time to satisfy their optimal nutritional requirements for a long time in this way, which tends to maximize their net rate of energy gain or minimize its loss. B. ovata of all sizes ingested both small and large prey. The finding that feeding on smaller specimens is effective is important when one considers the size structure of the Mnemiopsis leidyi population in the Caspian Sea, which, all year round, is mainly made up of small animals of less than $10 \mathrm{~mm}$ (Kideys \& Moghim 2003). Unfortunately, we do not know at which size they become lobate, though many small specimens in our experiments were noted to be lobate. It is worth noting that this smaller-sized M. leidyi without developed lobes have been observed not to have mature eggs (A. Moss \& A. E. Kideys unpubl.).

There was a correlation between digestion time and prey:predator weight ratio in B. ovata in our Caspian experiments that was similar to those observed at the Black Sea (at a salinity of 18 ppt; Finenko et al. 2001). However, this could be an artifact despite similar prey:predator ratios; the sizes of both ctenophores are larger in the Black Sea compared to those in the Caspian. Indeed, ctenophore digestion time from the latter was 1.5 times lower than that in the Black Sea.

The specific respiration rate of Beroe ovata in the Caspian Sea water was 1.5 to 2.3 times lower than those in the different regions of the Black Sea (Finenko et al. 2001, Shiganova et al. 2001a, Vostokov et al. 2001) and the Atlantic Ocean (Kremer et al. 1986), where it was calculated both in terms of wet wt and carbon content (Table 4). It is difficult to explain this difference in light of the effect of low salinity alone. Another reason could be the short acclimation period of ctenophores in our experiments to low salinity as opposed to the usual $2 \mathrm{wk}$ acclimation period given in published studies (Khlebovich 1974).

The coefficient of exponential growth $(k)$ can be used as a basis of comparison between different animals. The upper limit of the specific daily growth rate of gelatinous carnivores can be as high as $>70 \%$ in the early stages (i.e. during the first days of development) in a condition of nonlimited food availability that is reduced to low values as a result of temperature decrease or deterioration of food conditions (Table 5). The daily specific growth rate of Beroe ovata in Caspian Sea water was equal to 7 to $11 \%$ of body wet wt (disregarding 1 large $B$. ovata that lost weight at low feeding rate). These values were obtained for adult $B$. ovata with an initial length of $30 \mathrm{~mm}$ when daily rations ranged from 26 to $43 \%$ of body wet wt. Similar values were characteristic of the Black Sea B. ovata in laboratory feeding experiments when ctenophores consumed about $50 \%$ of their body wet wt daily (Finenko et al. 2003). Greve (1970) estimated the daily specific growth rate of the juvenile $B$. cucumis with a size of 5 to $15 \mathrm{~mm}$ to be as high as $40 \%$ of body wet wt at $16^{\circ} \mathrm{C}$ and Kamshilov (1960)

Table 4. Equations relating respiration rate in terms of wet weight (wet wt) and carbon content in Beroe ovata from different regions. Equation is of the form $R=\mathrm{a} W^{\mathrm{b}}$, where $R$ is respiration rate $\left(\mathrm{ml} \mathrm{O}_{2}\right.$ ind.$\left.^{-1} \mathrm{~h}^{-1}\right)$, both wet wt and carbon content are in $\mathrm{g}$, a and $\mathrm{b}$ are regression coefficients, $T$ is temperature

\begin{tabular}{|c|c|c|c|c|c|c|c|c|c|c|c|}
\hline \multirow[t]{2}{*}{$\begin{array}{c}T \\
\left({ }^{\circ} \mathrm{C}\right)\end{array}$} & \multirow[t]{2}{*}{ Region } & \multirow[t]{2}{*}{$\begin{array}{l}\text { Weight range } \\
\text { (g wet wt) }\end{array}$} & \multirow[t]{2}{*}{$\mathrm{S} \%$ o } & \multirow[t]{2}{*}{$\begin{array}{c}\mathrm{C} \% \\
\text { of } \\
\text { wet wt }\end{array}$} & \multicolumn{4}{|c|}{\begin{tabular}{ll}
\multicolumn{2}{c}{ Respiration rate } \\
(wet wt) & (carbon \\
& content)
\end{tabular}} & \multirow[t]{2}{*}{$\begin{array}{l}\text { Weight specific } \\
\text { respiration rate } \\
\left(\mathrm{ml} \mathrm{O}_{2} \mathrm{~g}^{-1} \text { wet } \mathrm{wt} \mathrm{h}^{-1}\right)\end{array}$} & \multirow[t]{2}{*}{$\begin{array}{l}\text { Carbon specific } \\
\text { respiration rate } \\
\left(\mathrm{ml} \mathrm{O}_{2} \mathrm{~g} \mathrm{C}^{-1} \mathrm{~h}^{-1}\right)\end{array}$} & \multirow[t]{2}{*}{ Source } \\
\hline & & & & & $\mathrm{a}$ & $\mathrm{b}$ & a & $\mathrm{b}$ & & & \\
\hline 25 & Bahamas & $0.15-37.5$ & 35.4 & 0.15 & 0.0084 & 0.90 & 2.860 & 0.90 & $0.010-0.006$ & $6.624-3.814$ & $\begin{array}{l}\text { Kremer } \\
\text { et al. (1986) }\end{array}$ \\
\hline 20 & $\begin{array}{l}\text { Sevastopol Bay, } \\
\text { Black Sea }\end{array}$ & Y, $\quad 0.4-48$ & 18 & 0.13 & 0.0074 & 1.04 & 7.237 & 1.04 & $0.007-0.009$ & $5.348-6.477$ & $\begin{array}{l}\text { Finenko } \\
\text { et al. (2001) }\end{array}$ \\
\hline 20 & $\begin{array}{l}\text { Blue Bay, } \\
\text { Black Sea }\end{array}$ & $3.2-80$ & 18 & 0.15 & 0.018 & 0.80 & 3.33 & 0.80 & $0.014-0.007$ & $9.774-5.135$ & $\begin{array}{l}\text { Vostokov } \\
\text { et al. (2001) }\end{array}$ \\
\hline 21 & $\begin{array}{l}\text { Caspian Sea } \\
\text { water }\end{array}$ & $0.23-3.86$ & 12.6 & 0.13 & 0.0052 & 1.02 & 4.48 & 1.02 & 0.005 & $3.808-4.030$ & Present study \\
\hline
\end{tabular}


reported the lowest values of 2 to $4 \%$ in the Barents Sea for the adult $B$. cucumis (unfortunately no temperature value is given, however, even in summer the sea surface temperature is rarely known to exceed $5^{\circ} \mathrm{C}$ ).

In the long-term experiment, growth, food and oxygen consumption rates were measured in the same animals. Assimilation efficiency was calculated by the difference between ration and assimilated (respiration

Table 5. Specific growth rate in gelatinous carnivores. $T$ : temperature

\begin{tabular}{|c|c|c|c|c|}
\hline Species & $\begin{array}{c}\mathrm{T} \\
\left({ }^{\circ} \mathrm{C}\right)\end{array}$ & $\begin{array}{l}\text { Size } \\
(\mathrm{mm})\end{array}$ & $\begin{array}{l}\text { Growth co- } \\
\text { efficient }(k)\end{array}$ & Source \\
\hline $\begin{array}{l}\text { Pleurobrachia } \\
\text { bachei }\end{array}$ & 20 & $\begin{array}{c}<2 \\
2-6.5 \\
>6.5\end{array}$ & $\begin{array}{l}0.12-0.17 \\
0.21-0.47 \\
0.04-0.17\end{array}$ & Hirota (1972) \\
\hline P. bachei & 15 & $\begin{array}{c}2.5-6.0 \\
6-10\end{array}$ & $\begin{array}{l}0.47 \\
0.09\end{array}$ & Reeve \& Walter (1976) \\
\hline $\begin{array}{l}\text { Mnemiopsis } \\
\text { mcradyi }\end{array}$ & $\begin{array}{l}20 \\
26\end{array}$ & $\begin{array}{c}<30 \\
30-40 \\
40-68\end{array}$ & $\begin{array}{l}0.76 \\
0.78 \\
0.23 \\
0.07\end{array}$ & Reeve \& Baker (1975) \\
\hline M. leidyi & 20 & & 0.25 & Miller (1970) \\
\hline M. leidyi & 22 & $2-5^{\mathrm{a}}$ & $0.28-0.38$ & $\begin{array}{l}\text { Finenko \& Romanova } \\
\text { (2000) }\end{array}$ \\
\hline $\begin{array}{l}\text { Bolinopsis infun- } \\
\text { dibulum }\end{array}$ & 16 & $10-40$ & 0.2 & Greve (1970) \\
\hline $\begin{array}{l}\text { Beroe cucumis } \\
\text { B. cucumis }\end{array}$ & 16 & $\begin{array}{r}15-30 \\
5-15\end{array}$ & $\begin{array}{c}0.02-0.04 \\
0.4\end{array}$ & $\begin{array}{l}\text { Kamshilov (1960) } \\
\text { Greve (1970) }\end{array}$ \\
\hline $\begin{array}{l}\text { B. ovata } \\
\text { B. ovata }\end{array}$ & $\begin{array}{l}22 \\
26\end{array}$ & $\begin{array}{l}16-65 \\
20-36\end{array}$ & $\begin{array}{c}0.1-0.2 \\
0.07-0.11\end{array}$ & $\begin{array}{l}\text { Finenko et al. (2003) } \\
\text { Present study }\end{array}$ \\
\hline $\begin{array}{l}\text { Aurelia aurita } \\
\text { A. aurita } \\
\text { A. aurita (ephyra) }\end{array}$ & $\begin{array}{c}15 \\
5-19 \\
6-18\end{array}$ & $4-9$ & $\begin{array}{c}0.22 \\
0.05-0.15 \\
0.16-0.31\end{array}$ & $\begin{array}{l}\text { Olesen et al. (1994) } \\
\text { Hansson (1997) } \\
\text { Bamstedt et al. (1999) }\end{array}$ \\
\hline $\begin{array}{l}\text { Cyanea capillata } \\
\text { (ephyra) }\end{array}$ & 10 & $2-20$ & $0.16-0.31$ & Bamstedt et al. (1997) \\
\hline \multicolumn{3}{|l|}{$\begin{array}{l}\text { Chrysaora quinquec- } \\
\text { cirrha (ephyra) }\end{array}$} & $0.3-0.7^{b}$ & Olesen et al. (1996) \\
\hline \multicolumn{5}{|c|}{$\begin{array}{l}{ }^{\mathrm{a}} \text { Food concentration is about } 2 \mathrm{mg} \mathrm{l}^{-1} \text { wet wt } \\
{ }^{\mathrm{b}} \text { Experiment lasted only for } 4 \mathrm{~d}\end{array}$} \\
\hline
\end{tabular}

plus growth rates) energy. Although the Beroe ovata laid some eggs, we did not include them in calculation because of their insignificance in regards to the energy budget. The assimilation, gross $\left(K_{1}\right)$ and net $\left(K_{2}\right)$ growth efficiencies correspond closely to that measured for other gelatinous carnivores (Table 6). The high values of gross and net growth efficiencies (up to 40 to $55 \%$ for $K_{1}$ and up to $80 \%$ for $K_{2}$ ) were observed in the high food provision of small animals where both coefficients decreased with ctenophore size.

Results of our experiments showed that Beroe ovata can spawn in the Caspian seawater and eggs can hatch. However, future experiments are needed to identify favorable conditions for egg development and larval growth.

Based on our physiological data, we suggest that in the Caspian Sea Beroe ovata is able to grow and ingest Mnemiopsis leidyi intensively and decrease its abundance sharply. The narrower limits of tolerance to salinity are typical for initial ontogenetic stages in marine organisms (Sarantchova 2001). During ontogenesis the salinity range generally becomes wider. In our experiments, B. ovata larvae could be more sensitive to the lower salinity of the Caspian Sea compared to adult ctenophores, and this could be one of the other reasons for the failure to grow larvae in our experiments. However, we strongly think that mainly the poor handling (i.e. the back filtration method used to separate the larvae) must have caused this failure.

It is worthwhile noting that some other studies (e.g. on parasites, feeding with other native organisms, mod-

Table 6. Assimilation, gross and net growth efficiencies (\%) in gelatinous predators

\begin{tabular}{|lcccl|}
\hline Species & $\begin{array}{c}\text { Assimilation } \\
\text { A }\end{array}$ & $\begin{array}{c}\text { Gross growth } \\
\text { efficiency } K_{1}\end{array}$ & $\begin{array}{c}\text { Net growth } \\
\text { efficiency } K_{2}\end{array}$ & Source \\
\hline Mnemiopsis leidyi & 75 & & & Reeve et al. (1978) \\
M. leidyi & 72 & 40 & $59-80$ & Reeve et al. (1989) \\
M. leidyi & & $20-40$ & & Fremer \& Reeve (1989) \\
M. leidyi & & $30-55$ & & Finenko et al. (2003) \\
Beroe ovata & $16-31$ & $0.66 \pm 0.04$ & Present study \\
B. ovata & $0.73 \pm 0.09$ & $0.48 \pm 0.09$ & & Purcell (1983) \\
Siphonophores (4 species) & $87-94$ & & 35 & Reeve et al. (1978) \\
Pleurobrachia bachei & 74 & & Olesen et al. (1994) \\
Aurelia aurita & & & & \\
\hline
\end{tabular}


eling etc.) relating to the possible impact of this potential intentional introduction are still necessary. If the results of these studies are also convincing, the predator Beroe ovata would be a vitally important bio-control agent against Mnemiopsis leidyi, which causes immense ecological and economical problems in the Caspian Sea. Our results presented here are therefore important as a first step in indicating the feasibility of this introduction.

Acknowledgements. This study was made possible by the organizational efforts of Dr. V. Vladymyrov (Caspian Environment Program, CEP) under the financial support of UNOPS through CEP, project RER98G32 and IFRO (Iranian Fisheries Research Organization) Tehran. We appreciate the hospitality and kind help of Mazandaran Fisheries Research Center and IFRO personnel including Drs. S. Rezvani (Head of IFRO), A. Salmani, S. Ghasemi, F. Parafkandeh, M. Najafpour, M. Nazaran, A. R. Kihansani, J. Sharifi, T. M. Pormand, A. Nasrollatabar, M. Ebrahimzadeh, A. Jafarei and R. Ahmedinejad. Our special thanks go to Dr. Pat Kremer for her thorough and constructive comments.

\section{LITERATURE CITED}

Anninsky BE (1994) Organic matter composition of the jellyfish Aurelia aurita and two species of ctenophores from the Black Sea (in Russian). Biol Morya 20:291-295

Bamstedt U, Ishii H, Martinussen MB (1997) Is the scyphomedusa Cyanea capillata (L.) dependent on gelatinous prey for its early development? Sarsia 82:269-273

Bamstedt U, Lane J, Martinussen MB (1999) Bioenergetics of ephyra larvae of the scyphozoan jellyfish Aurelia aurita in relation to temperature and salinity. Mar Biol 135:89-98

Dumont H (1995) Ecocide in the Caspian. Nature 377:673-674

Finenko GA, Romanova ZA (2000) Population dynamics and energetics of ctenophore Mnemiopsis leidyi in Sevastopol Bay. Oceanology 40:677-685

Finenko GA, Romanova ZA, Abolmasova GI (2000) The ctenophore Beroe ovata is a new invader to the Black Sea (in Russian). Ecol Morya 50:19-22

Finenko GA, Anninsky BE, Romanova ZA, Abolmasova GI, Kideys AE (2001) Chemical composition, respiration and feeding rates of the new alien ctenophore, Beroe ovata, in the Black Sea. Hydrobiologia 451:177-186

Finenko GA, Romanova ZA, Abolmasova GI, Anninsky BE, Svetlichny LS, Hubareva ES, Bat L, Kideys AE (2003) Ingestion, growth and reproduction rates of the alien Beroe ovata and its impact on the plankton community in Sevastopol Bay (the Black Sea). J Plankton Res 25:539-549

GESAMP (1997) Opportunistic settlers and the problem of the ctenophore Mnemiopsis leidyi invasion in the Black Sea. Reports and Studies no. 58, GESAMP (Joint Group of Experts on the Scientific Aspects of Marine Environmental Protection), London

Greve W (1970) Cultivation experiments on North Sea ctenophores. Helgol Meeresunters 20:304-317

Gubanova AD, Prusova IYU, Niermann U, Shadrin NV, Polikarpov IG (2001) Dramatic change in the copepod community in Sevastopol Bay (Black Sea) during 2 decades (1976-1996). Senckenb Marit 31:17-27

Hansson LJ (1997) Effect of temperature on growth rate of Aurelia aurita (Cnidaria, Scyphozoa) from Gullmarsfjorden, Sweden. Mar Ecol Prog Ser 161:145-153
Hirota J (1972) Laboratory culture and metabolism of the planktonic ctenophore Pleurobrachia bachei A. Agassiz. In: A.Y. Takenouti et al. (eds) Biological oceanography of the northern North Pacific Ocean. Idemitsu Shoten, Tokyo, p 465-484

Ivanov PI, Kamakim AM, Ushivtzev VB, Shiganova T and 5 others (2000) Invasion of Caspian Sea by the comb jellyfish Mnemiopsis leidyi (Ctenophora). Biol Invasions 2: 255-258

Kamshilov MM (1960) Relationship between the size and feeding of the ctenophore Beroe cucumis Fabricius. Dolk Akad Nauk SSSR 131:957-960

Khlebovich VV (1974) Critical salinity of biological processes (in Russian). L. Nauka, Moscow, p 325

Kideys AE (1994) Recent dramatic changes in the Black Sea ecosystem: The reason for the sharp decrease in Turkish anchovy fisheries. J Mar Syst 5:171-181

Kideys AE (2002) Fall and rise of the Black Sea ecosystem. Science 297:1482-1484

Kideys AE, Moghim M (2003) Distribution of the alien ctenophore Mnemiopsis leidyi in the Caspian Sea in August 2001. Mar Biol 142:163-171

Kideys AE, Romanova Z (2001) Distribution of macrogelatinous zooplankton in the southern Black Sea during 1996-1999. Mar Biol 139:535-547

Kideys AE, Kovalev AV, Shulman G, Gordina A, Bingel F (2000) A review of zooplankton investigations of the Black Sea over the last decade. J Mar Syst 24:355-371

Kideys AE, Ghasemi S, Ghninejad D, Roohi A, Bagheri S (2001a) Strategy for combating Mnemiopsis in the Caspian waters of Iran. Final Report, July 2001, Caspian Environment Programme, Baku, Azerbaijan

Kideys AE, Jafarov FM, Kuliyev Z, Zarbalieva T (2001b) Monitoring Mnemiopsis in the Caspian waters of Azerbaijan. Final Report, August 2001, Caspian Environment Programme, Baku, Azerbaijan

Kremer P, Nixon S (1976) Distribution and abundance of the ctenophore Mnemiopsis leidyi in Narragansett Bay. Estuar Coast Mar Sci 4:627-639

Kremer P, Reeve MR (1989) Growth dynamics of a ctenophore (Mnemiopsis) in relation to variable food supply. II. Carbon budgets and growth model. J Plankton Res 11:553-574

Kremer P, Canino MF, Gilmer RW (1986) Metabolism of epipelagic ctenophores. Mar Biol 90:403-412

Miller RJ (1970) Distribution and energetics of an estuarine population of the ctenophore, Mnemiopsis leidyi. $\mathrm{PhD}$ thesis, North Carolina State University, Raleigh, NC

Mutlu E (1999) Distribution and abundance of ctenophores, and their zooplankton food in the Black Sea. II. Mnemiopsis leidyi. Mar Biol 135:603-613

Olesen NJ, Frandsen K, Riisgard HU (1994) Population dynamics, growth and energetics of the jellyfish Aurelia aurita in a shallow fjord. Mar Ecol Prog Ser 105:9-18

Olesen NJ, Purcell JE, Stoecker DK (1996) Feeding and growth by ephyrae of scyphomedusae Chrysaora quinquecirrha. Mar Ecol Prog Ser 137:149-159

Prodanov $\mathrm{K}$, Mikhailov KG, Daskalov $\mathrm{K}$, Chashchin A, Arkhipov A, Shlyakhov V, Ozdamar E (1997) Environmental impact on fish resources in the Black Sea. In: Ozsoy E, Mikaelyan A (eds) Sensitivity of the North Sea, Baltic Sea and Black Sea to anthropogenic and climatic changes. Kluwer, Dordrecht p 163-181

Purcell JE (1983) Digestion rates and assimilation efficiencies of Siphonophores fed zooplankton prey. Mar Biol 73: 257-262

Reeve MR, Baker LD (1975) Production of two planktonic carnivores (chaetognath and ctenophore) in south Florida 
inshore waters. Fish Bull 73:238-248

Reeve MR, Walter MA (1976) A large-scale experiment on the growth and predation potential of ctenophore populations. In: Macki GO (ed) Coelenterate ecology and behavior. Plenum Press, New York, p 187-199

Reeve MR, Walter MA, Ikeda T (1978) Laboratory studies of ingestion and food utilization in lobate and tentaculate ctenophores. Limnol Oceanogr 23:740-751

Reeve MR, Syms MA, Kremer P (1989) Growth dynamics of a ctenophore (Mnemiopsis) in relation to variable food supply. I. Carbon biomass, feeding, egg production, growth and assimilation efficiency. J Plankton Res 11:535-552

Sarantchova OL (2001) Research into tolerance for 5 the environment salinity in sea starfish Asterias rubens L. from populations of the White Sea and Barents Sea. J Exp Mar Biol Ecol 264:15-28

Shiganova TA (1997) Mnemiopsis leidyi abundance in the Black Sea and its impact on the pelagic community. In: Ozsoy E, Mikaelyan A (eds) Sensitivity of the North Sea, Baltic Sea and Black Sea to anthropogenic and climatic changes. Kluwer, Dordrecht, p 117-130

Shiganova TA (1998) Invasion of the Black Sea by the ctenophore Mnemiopsis leidyi and recent changes in

Editorial responsibility: Otto Kinne (Editor),

Oldendorf/Luhe, Germany pelagic community structure. Fish Oceanogr 7:305-310

Shiganova TA, Bulgakova YV, Sorokin PJ, Lukashev JF (2000) Results of the study of the new alien Beroe ovata in the Black Sea (in Russian). Biol Bull 2:247-255

Shiganova TA, Bulgakova YV, Volovik SP, Mirzoyan ZA, Dudkin SI (2001a) The new invader Beroe ovata Mayer 1912 and its effect on the ecosystem in the northeastern Black Sea. Hydrobiologia 451:187-197

Shiganova TA, Kamakin AM, Zhukova OP, Ushivtzev VB, Dulimov AB, Musaeva EI (2001b) An invader in the Caspian Sea: ctenophore Mnemiopsis and its initial effect on pelagic ecosystem. Oceanology 41:1-9

Strickland JDH, Parsons TRA (1972) A practical handbook of seawater analysis. Bull Fish Res Board Can 167

Vinogradov ME, Shushkina EA, Musaeva EI, Sorokin PY (1989) Ctenophore Mnemiopsis leidyi (A. Agassiz) (Ctenophora: Lobata): new settler in the Black Sea. Oceanology 29:220-224

Vostokov SV, Arashkevich EG, Drits AV, Lukashev YF (2001) Ecological and physiological characteristics of the Ctenophore Beroe ovata in the coastal waters of the Black Sea: quantity, biomass, size distribution, hunting behaviour, feeding and metabolism. Oceanology 41:105-110

Submitted: December 2, 2002; Accepted: October 14, 2003

Proofs received from author(s): January 26, 2004 